\title{
FAKTOR-FAKTOR YANG MEMPENGARUHI PROFESIONALISME GURU MTS NEGERI DI BALIKPAPAN TIMUR
}

\author{
Tutik Yuliani \\ FKIP, Universitas Balikpapan \\ yulianie_tutik@yahoo.com
}

\begin{abstract}
This study aims to determine whether there is (1) Effect on Teacher's Competence towards Their Professionalism (2) Influence of School Organizational Climate on Teacher's Professionalism, and (3) Attitude towards Teacher's Professionalism. Sample in this research is all teachers in State MTS in East Balikpapan. Technique for collecting the data were using questionnaires and documentation. Results of this study are teacher's competence, organizational climate and attitudes simultaneously influence professionalism of teachers in State MTS in East Balikpapan. We can conclude that School Organizational Climate has a dominant influence on the professionalism of teachers in East Balikpapan.
\end{abstract}

Keywords: Teacher's Competence, School Organizational Climate, Attitudes, Teacher's Professionalism.

ABSTRAK. Penelitian ini bertujuan untuk mengetahui ada tidaknya (1) Pengaruh Kompetansi Guru terhadap Profesional Guru (2) Pengaruh Iklim Organisasi Sekolah terhadap Profesional Guru, serta (3) Sikap terhadap Profesional Guru. Sampel dalam penelitian ini adalah semua guru di MTS Negeri di Balikpapan Timur. Cara pengambilan data menggunakan kuesioner dan dokumentasi. Hasil dari penelitian ini adalah kompetensi guru, iklim organisasi dan sikap berpengaruh secara serentak terhadap profesionalisme guru di MTS Negeri di Balikpapan Timur. Iklim organisasi sekolah memiliki pengaruh yang paling dominan terhadap profesionalisme guru di Balikpapan Timur.

Kata Kunci: Kompetensi Guru, Iklim Organisasi Sekolah, Sikap, Profesional Guru.

\section{PENDAHULUAN}

Profesi guru membutuhkan keahlian khusus, dan berperan penting dalam kegiatan pembelajaran, maka guru diharapkan mampu menjadi pendidik yang profesional tidak hanya dalam mengajar, tetapi juga mampu memecahkan masalah yang dihadapi siswa serta memberikan penyelesaian dari masalah tersebut, tetapi 
yang terjadi saat ini guru hanya berperan sebagai pengajar yang berdiri didepan kelas untuk menyampaikan pelajaran tanpa meninjau permasalahan yang dialamai siswa Profesional berasal dari kata profesi yang mempunyai arti pada suatu pekerjaan yang menuntut keahlian ,tanggung jawab, dan kesetiaan pada pekerjaan. Sedangkan kata profesional menunjuk pada dua hal yakni orangnya dan penampilan atau kinerja orang tersebut dalam melaksanakan tugas atau pekerjaanya. Ada beberapa faktor yang mempengruhi profesionalisme antara lain kompetensi guru, iklim organisasi, sikap.

Kompetensi merupakan salah satu faktor yang mempengaruhi profesionalisme gurur. Kompetensi adalah kegiatan yang bisa diamati yang mencangkup aspek-aspek pengetahuan, keterampilan, nilai, sikap, serta tahap-tahap pelaksanaannya secara utuh (Mulyasa.2008;40). Kompetensi guru merupakan perpaduan antara kemampuan personal, keilmuan, teknologi, sosial, dan spiritual yang secara kaffah membentuk kompetensi standar profesi guru, yang mencakup penguasaan materi, pemahaman terhadap peserta didik, pembelajaran yang mendidik, pengembangan pribadi dan profesionalisme. Mulyasa.(2008;26).

Faktor lain yang mempengaruhi profesionalisme guru adalah iklim organisasi, yaitu keseluruhan "perasaan" yang meliputi hal-hal fisik, bagaimana para anggota berinteraksi dan bagaimana para anggota organisasi mengendalikan diri dalam berhubungan dengan pelanggan atau pihak luar organisasi (Sopiah,2011;130) . Tipetipe dalam iklim organisasi bermacam-macam seperti iklim terkendali, iklim lepas, iklim tertutup, iklim terbuka, dimana semua tipe iklim ini sangat memberikan pengaruh terhadap profesionalisme guru.

Selain kompetensi dan iklim organisas sikap juga merupakan faktor yang mempengaruhi profesionalisme guru. Menurut LL. Thurstone: sikap adalah tingkatan kecenderungan yang bersifat positif atau negatif yang berhubungan dengan objek psikologis yang berupa simbol-simbol rata-rata, slogan-slogan, orang, lembaga, ide dan sebagainya. (Bimo Walgito,1983:51) sedangkan menurut D. Krech dan Crutch field: sikap adalah organisasi yang tetap dari profesi motivasi, emosi, persepsi, atau 
pengamatan atas suatu aspek dari kehidupan individu. (Siti Partini,1989:62), sikap merupakan sesuatu yang mengarah pada tujuan yang dihadapi dalam bentuk tindakan, ucapan, perbuatan , maupun emosi seseorang (Danang Sunyoto. 2012:275). Dalam sikap terdapat beberapa komponen yang dapat diperhatikan untuk meningkatkan profesionalisme guru, komponen tersebut dapat berupa komponen kognitif, komponen efektif, komponen perilaku,

MTs Negeri di Balikpapan Timur merupakan salah satu MTs negeri yang ada di kota Balikpapan. Observasi yang telah dilakukan bahwa semua guru dalam melakukan proses belajar mengajar cukup bagus, hanya saja ada beberapa guru yang belum memanfaatkan media yang telah ada di sekolah seperti laptop, LCD selain itu ada beberapa guru belum membuat perangkat pembelajaran. Dilihat dari ilim organisasi masih terlihat ada beberapa guru yang kurang aktif dalam kegiatan sehingga seperti kurang ada kekompokan antara satu guru dengan guru yang lain. Sedangkan dilihat dari sisi sikap masih ada beberapa diantara guru yang sering berbeda pendapat antara satu guru dengan guru yang lain tetapi hal ini bisa diatasi oleh sikap kepala sekolah yang mampu mengayomi serta memberikan kebebasan berinovasi kepada semua guru sehingga guru lebih merasa dihargai. Dalam mencapai profesionalisme yang baik maka diperlukan adanya kompetensi, iklim organisasi dan sikap guru yang bagus. Maka penulis mengangkat permasalahan dalam bentuk penelitian dengan judul faktor-aktor yang mempengaruhi profesional guru MTs Negeri di Balikpapan Timur

\section{METODELOGI}

Jenis penelitian ini adalah penelitian kuantitatif yang digunakan peneliti dengan menggunakan sampel. Penelitian dibagi dalam beberapa tahap, yaitu tahap perencanaan, tahap pelaksanaan, tahap penyelesaian. Subyek penelitian ini adalah semua guru MTs Negeri di Balikpapan Timur. Dalam penelitian tiga variabel independen dan satu variabel dependen. Kompetensi, iklim organisasi dan sikap sebagai variabel independen atau bebas sedangkan profesionalisme guru sebagai 
variabel terikat atau dependen. Untuk memberikan gambaran tentang variabel terikat dan variabel bebas dapat dilihat pada gambar sebagai berikut:

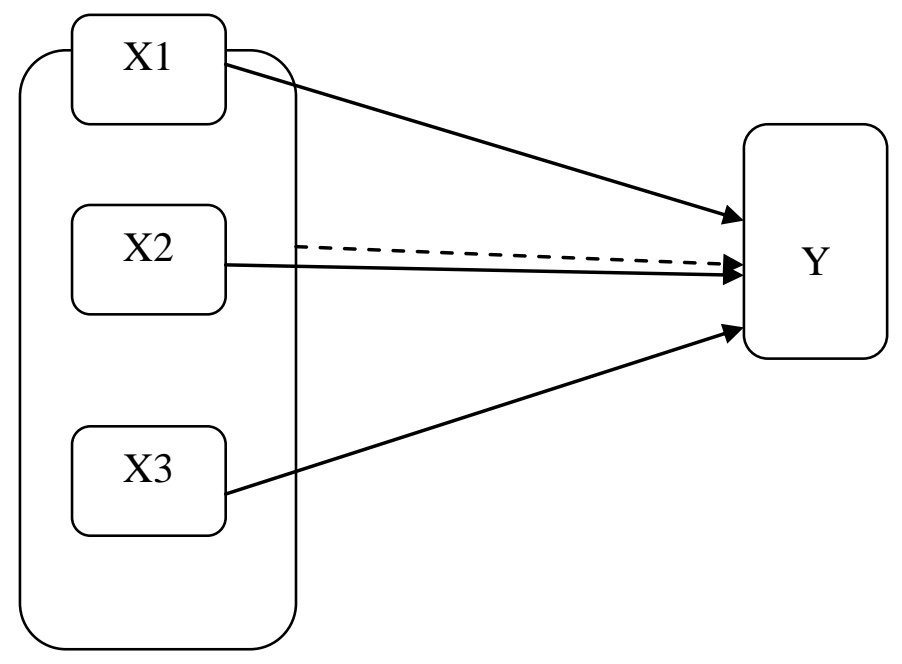

Gambar 1. Rancangan Penelitian

Keterangan:

$\mathrm{X} 1$ : Kompetensi guru

$\mathrm{X} 2$ : Iklim organisasi

X3 : Sikap

$\mathrm{Y}$ : Profesionalisme guru

$\longrightarrow$ : secara parsial

- - - - - - : secara serentak

Populasi dalam penelitian adalah semua guru MTs negeri di Balikpapan Timur. Adapun data dalam penelitian ini diperoleh dari guru MTs negeri di Balikpapan Timur. Teknik pengumpulan data dalam penelitian ini menggunakan teknik kuesioner (angket), dokumentasi Teknik Analisis data menggunakan uji t untuk mengetahui faktor-faktor yang mempengaruhi profesionalisme guru secara parsial dan uji $\mathrm{F}$ untuk mengetahui faktor-faktor yang mempengaruhi profesional guru secara bersama-sama 


\section{HASIL DAN PEMBAHASAN}

Profesionalisme guru dipengaruhi oleh banyak factor, tetapi pada penelitian ini akan membahas pengaruh kompetensi guru, iklim dan sikap terhadap profesional guru di MTs Negeri di Balikpapan Timur

Tabel. 1. Hasil analisis

\begin{tabular}{l|r|r|r|r}
\hline Variabel & \multicolumn{1}{c}{ B } & t hitung & \multicolumn{1}{c}{ sig } & \multicolumn{1}{c}{ r partial } \\
\hline (Constant) & 1.091 & 2.466 & .017 & \\
Kompetensi guru & .165 & 2.124 & .039 & .296 \\
Iklim organisasi sekolah & .318 & 2.392 & .021 & .329 \\
sikap & .247 & 2.273 & .028 & .315 \\
\hline F hitung & 10.607 & \\
Sip F hitung & .000
\end{tabular}

Sumber: Data diolah

\section{Secara Serentak atau Secara bersama}

Dari tabel 1 menunjukan bahwa terdapat pengaruh secara bersama-sama atau secara serentak antara kompetensi guru, iklim organisasi sekolah, dan sikap terhadap profesional guru MTs Negeri di Balikpapan. Timur. Hal ini ditunjukkan bahwa sig nilai F hitung (0.000) lebih besar dari 5\% atau 0.05.

Kompetensi guru ini meliputi kompetensi pedagogik, kompetensi sosial, kompetensi profesional, dan kompetensi kepribadian dengan memiliki kompetensi tersebut guru mampu mengajar dengan baik sehingga dalam pelakasanaan kegiatan belajar mengajar guru sudah memiliki sebagian dari sikap professional guru tersebut. Cara penyampaian materi guru di MTs negeri di Balikpapan Timur dapat membuat siswa tidak bosan hal ini terlihat dari kelas selalu ada tanya jawab. walaupun cara menyampaikan materi masih ada yang belum menggunakan media seperti LCD.

Iklim organisasi sekolah berpengaruh terhadap professional guru sebesar $32,9 \%$, iklim organisasi sekolah ini meliputi misi, tujuan - tujuan, sasaran - sasaran, 
dan perilaku. dengan memiliki iklim organisasi sekolah tersebut guru mampu berorganisasi dengan baik, sehingga dalam kegiatan didalam maupun diluar pelajaran guru tetap memiliki sebagian dari sikap professional guru tersebut. Dalam kegiatan tertentu ada beberapa guru kurang aktif sehingga terlihat kurang kompak, tetapi meskipun hal itu terjadi sebagian guru di MTs ini selalu berbagi pengetahuan yang dimiliki apabila terdapat guru yang tidak aktif dalam kegiatan sehingga hal ini membuat iklim organisasi masih cukup baik.

Sikap juga berpengaruh terhadap professional guru sebesar $31,5 \%$ sikap ini meliputi sikap selalu memiliki objek, sikap mempunyai arah, siakap mempunyai struktur dan krangka organisasi, serta sikap proses, dengan memiliki sikap tersebut guru mampu melaksanakan kegiatan belajar mengajar dengan baik sehingga mampu mengatasi permasalahan - permasalahan yang terjadi di lingkungan sekolah. Sikap guru terhadap pekerjaannya memiliki arti sebagai tindakan yang telah dilakukan dari pekerjaan yang dipikulnya.. Guru yang mempunyai sikap positif pada pekerjaannya, pasti akan memberikan kepuasan dari pekerjaanya sehingga dapat memberikan motivasi pada guru tersebut, yang akhirnya akan memberikan pandangan bahwa seorang guru yang dapat bekerja dengan penuh tanggung jawab. Guru yang mempunyai rasa tanggung jawab niscaya akan dapat menjalankan pekerjaannya dengan baik. Oleh sebab itu dengan sikap yang positif pada pekerjaannya seorang guru akan mampu bertindak sesuai tanggungjawabnya dengan baik, sehingga mereka mempunyai kemampuan yang profesional.

\section{Secara Parsial}

Secara parsial kompetensi guru, iklim organisasi sekolah, sikap mempunyai pengaruh terhadap profesional guru di MTs negeri di Balikpapan Timur, ini ditunjukkan bahwa nilai sig tiap-tiap variabel <0,05, yaitu kompetensi guru 0,039< 0,05, iklim organisasi sekolah $0,021<0,05$ dan sikap $0,028<0.05$.

Variabel yang diteliti dalam penelitian ini semuanya secara parsial memliki pengaruh terhadap profesionalisme guru, Akan tetapi setelah dilakukan penelitian, 
variabel yang memiliki pengaruh yang paling besar atau yang memiliki pengaruh yang dominan terhadap profesionalisme guru adalah iklim organisasi. Hal ini dapat dilihat pada tabel 1 variabel iklim organisai sekolah (X2) hasil uji parsial (uji t) sebesar 2.273 yang berarti $>t_{\text {kritis }}$ dan nilai signifikan $<0.05$. Koefisien determinasi parsial diperoleh kesimpulan bahwa besarnya kontribusi iklim organisasi sekolah terhadap profesional guru di MTs Negeri di Balikpapan Timur adalah sebesar 31,5\%. Variabel iklim organisasi sekolah (X2) memiliki koefisien determinasi parsial lebih tinggi daripada variabel kompetensi guru (X1). Walaupun hanya memiliki sedikit perbedaan kedua variabel tersebut sama - sama memberikan pengaruh yang positif.

\section{Kesimpulan}

Secara parsial maupun secara serentak kompetensi, iklim organisasi dan sikap perpengaruh terhadap profesional guru. Diantara kompetensi, iklim organisasi dan sikap yang memiliki pengaruh paling besar adalah iklim organisasi.

\section{Saran}

1. Guru perlu terus meningkatkan kompetensi guru, iklim organisas sekolah serta sikap yang dimiliki agar profesional guru juga terus meningkat menjadi lebih bagus dan dapat meningkatkan kualitas pendidikan guru di MTs Negeri di Balikpapan Timur dimasa yang akan datang.

2. Kepala sekolah perlu untuk lebih memperhatikan kompetensi guru, iklim organisasi sekolah, dan sikap setiap guru, agar guru lebih terarah dalam setiap kegiatan sehingga dimasa yang akan datang semua guru akan memiliki kompetensi, iklim organisasi sekolah, dan sikap yang jauh lebih baik lagi. 


\section{DAFTAR PUSTAKA}

Bafadal, Ibrahim, 1996. Pengelolaan Perpustakaan Sekolah. Jakarta; Bumi Aksara.

Daryanto, 2013. Standard Kompetensi dan Penilaian Kinerja Guru Profesional. Yogyakarta: Diterbitkan oleh Gava Media Klitren Lor Gk III/ 15.

Danang Sunyoto, Konsep Dasar Riset pemasaran \& Prilaku Konsumen. Yogyakarta: PT. Buku Seru Jl. Kelapa Hijau No. 22 RT. 006/03.

Gunawan, Ali. 2013. Statistik Penelitian Pendidikan, Jogjakarta,Parama Publishing.

Jubile,2014. SPSS untuk Pemula, Jakarta: PT Elex Media Komputindo.

Muhaimin, Suti'ah, Sugeng Listyo Prabowo. 2009. Manajemen Pendididkan Aplikasi Dalam Penyusunan Rencaana Pengembangan Sekolah/Madrasah. Jakarta: Jl. Tambra Raya No. 23 Rawamangun.

Mulyasa, 2010. Kurikulum Berbasis Kompetensi Konsep, Karakteristik, dan Implementasi. Bandung: Remaja Rosdakarya.

Mulyasa. 2008. Standar Kompetensi dan Sertifikasi Guru. Bandung: Remaja Rosdakarya.

Natanael, Yonathan, dan Sufren. 2014. Belajar Otodidak SPSS Pasti Bisa, Jakarta, PT Elex Media Komputindo.

Priansa, Doni Juni. 2014. Kinerja dan Profesionalisme Guru. Alfabeta.

Sopian. 2011. Prilaku Organisasional. Andi.

Suparlan.2006. Guru Sebagai Profesi.Yogyakarta: Hikayat Publishing, Jl. Lowanu No. 55.

Sugiono, 2010. Metode Penelitian Kuantitatif, Kualitatif, dan $R$ dan D. Bandung: Alfabeta.

Syah, Muhhibin, 1995. Psikologi Pendidikan.Bandung: Remaja Rosdakarya.

Uno,Hamzah B. 2008. Perencanaan Pembelajaran. Bumi Aksara. 
Tim Dosen Administrasi Pendidikan Universitas Pendidikan Indonesia. 2011. Manajemen Pendidikaan. Bandung: Alfabeta.

Wahjosumidjo. 1999, Kepemimpinan Kepala Sekolah. Jakarta: Pt. Raja Grafindo Persada, Jl. Pelepah Hijau IV TN. 1 No. 14-15, Kelapa Gading Permai.

Wahyudi. 2009. Kepemimpinan Kepala Sekolah dalam Organisasi Pembelajaran. Alfabeta.

Walgito, Bimo.1985.Bimbingan dan Penyuluhan di Sekolah.Yogyakarta: fak. Pskilogi UGM.

Natanael, Yonathan, dan Sufren. 2014. Belajar Otodidak SPSS Pasti Bisa, Jakarta, PT Elex Media Komputindo. 